\title{
Physicochemical Properties of the Soils of Wassaniya Forest Reserve Tangaza Local Government, Sokoto State
}

\author{
${ }^{1}$ M. Atiku and ${ }^{2}$ S.S. Noma \\ ${ }^{1}$ Department of Forestry and Fisheries, Kebbi State University of Science and Technology, Aliero. \\ ${ }^{2}$ Department of Soil Science and Agricultural Engineering, Usmanu Danfodiyo University, Sokoto. \\ [* Corresponding Author: Email: atiku.bajida @ yahoo.com. Tel.: +2348038028660]
}

\begin{abstract}
A study was conducted on the physical and chemical properties of the soils of Wassaniya Forest Reserve in Tangaza Local Government Area of Sokoto State, Nigeria. The study area was divided into 4 main plots located at Wassaniya, Jimajimi, Yartagimba and Daiji purposively selected based on vegetation density and human interference. From each of the four main plots three sample plots of size 0.5 ha were randomly selected and demarcated to serve as replicates. Four composite soil samples were collected at the depth of 0 to $15 \mathrm{~cm}$ from each plot using a soil auger for laboratory analyses. Four other undisturbed soil samples were collected for bulk density determination using a core sampler. The soils at the four locations varied in texture from sandy loam (SL) at Yartagimba, clay loam (CL) at Wassaniya and Daiji to clay (C) at Jimajimi. The results indicated that the soils at Jimajimi had the highest moisture contents (9\%) though not statistically significant. The highest $\mathrm{pH}$ value (6.94) was obtained in the soils of Jimajimi which are slightly alkaline compared with the soils of Yartagimba (5.47) as well as those at Wassaniya and Daiji with $\mathrm{pH}$ values of 4.23 which connotes acidic reaction. Yartagimba had the highest Bulk density $\left(1.32 \mathrm{Mg} / \mathrm{m}^{3}\right)$, organic carbon $(1.64 \mathrm{~g} / \mathrm{kg})$ exchangeable potassium $(0.88 \mathrm{cmol} / \mathrm{kg})$ as well as highest nitrogen $(0.49 \mathrm{~g} / \mathrm{kg})$ hence the soils are more fertile.
\end{abstract}

Keywords: Physico-chemical properties, Soils, Wassaniya, Forest reserve

\section{INTRODUCTION}

The fertility of a soil is determined by both its physical properties and its nutrients. In regions where rainfall is generally less water supply is frequently the factor that determines crop growth. Essential elements are needed for both plant and animal growth as they form part of plant tissues; they act as catalyst or intermediates in a wide range of metabolic processes, (Evans et al., 1987). Increase in organic carbon content of the soil is known to increase the cation exchange capacity of the soil. Any decline in soil organic matter content could involve significant loss in nutrients and exchangeable bases. Increase in organic carbon might increase calcium storage of the top soil through increase in exchange capacity. In most of our forest reserves the nature of the soils has not been investigated, hence the fertility status of the soils is not known hence the objective of this study was to investigate the physicochemical properties of the soils of Wassaniya Forest Reserve.

\section{MATERIALS AND METHODS}

Study Area: Wassaniya Forest Reserve is located between Tangaza and Gudu Local Government areas of Sokoto State, Nigeria. It lies between Lat. $13^{0} 30 \hat{\text { to }} 13^{0} 34 \hat{\alpha}$ and Long. $42^{0} 32$ ô to $42^{0}$ 53đ̃E. Some villages surrounding the area includes: Yartagimba, Mulawa, Tungar noma, Tungar filani, Daiji, Marakenbori, Wassaniya, Masallaci, Jimajimi and Manu.

Underlayed organic material was removed using a spade; auger was used for collecting soil samples at $0-15 \mathrm{~cm}$ depth at each sampling spot. The samples were ground, sieved and passed through a $2 \mathrm{~mm}$ sieve; as in (Olaitan et al., 1988). Soil moisture contents were determined by Gravimetric method as in Miller and Donahue (1965). The collected soil samples were taken to the laboratory, weighed and later oven dried $100^{\circ} \mathrm{C}$ for 24 hours. The oven dry weight was then subtracted from the initial weight and the values expressed as percentages. 
Bulk Density: The oven- dried soil samples from the cores were removed and weighed. The volume of the core was determined and bulk density was calculated as mass of the dry soil divided by volume of the core, (B.D = Oven dry weight/Volume of soil) as in Blake (1965). The $\mathrm{pH}$ of the soil samples was determined using a glass electrode $\mathrm{pH}$ meter as described by Bates (1974). The exchangeable bases sodium ( $\mathrm{Na}$ ) and potassium $(\mathrm{K})$ were determined using a flame photometer, where as calcium (Ca) and magnesium $(\mathrm{Mg})$ were determined using the EDTA titration method as in Evans et.al (1987).

Cation exchange capacity (C.E.C): This was determined for each soil by summing up the values of exchangeable bases and exchangeable acidity for each soil in each sample plot as described by (Olaitan et.al., 1988). The organic carbon content was analyzed from the soil samples using Walkley-Black method (1934). The soil samples were oxidized with standard potassium dichromate solution; the excess dichromate solution was then titrated with standard ferrous ammonium sulphate. Particle size distribution was determined using modified Bouyoucos hydrometer method as described by Day (1959).

\section{RESULTS AND DISCUSSION}

Soil moisture content: The results indicated that the moisture content of the soils from the four locations were found statistically not significant (P>0.05), (Table 1). At Jimajimi it was 9\%, in Wassaniya and Yartagimba the moisture content was $8 \%$, and $7.5 \%$ at Daiji. Soil moisture is required for plant growth and nutrient utilization by plants. The moisture content was generally low due to lower rainfall as opined by Illeoje (1985) to be one of the main characteristic of savannah regions.

Bulk density: The bulk density of soils from the different locations had no significant difference $(\mathrm{P}>0.05)$ Yartagimba had $\left(1.32 \mathrm{Mg} / \mathrm{m}^{3}\right)$, Wassaniya $\left(1.29 \mathrm{Mg} / \mathrm{m}^{3}\right)$, Daiji $\left(1.27 \mathrm{Mg} / \mathrm{m}^{3}\right)$ and Jimajimi (1.25 Mg/m ${ }^{3}$ ) (Table 1).

Soil pH: There were variations in soil $\mathrm{pH}$ levels from the soil samples analyzed. Jimajimi had (6.94) making alkaline and was statistically higher
$(\mathrm{P}<0.05)$ than that of Yartagimba (5.47) which is slightly acidic. The $\mathrm{pH}$ values obtained at Wassaniya and Daiji were the same (4.23) (Table1). From the results obtained, the soils of Wassaniya (4.33) and Yartagimba (5.47) were found to be acidic characteristics of degraded soils. However soils at Jimajimi and Yartagimba, were found to be slightly acidic $(5.6-6.8)$. This level of $\mathrm{pH}$ is more preferred by most crops and trees. These $\mathrm{pH}$ values are in contrast with those obtained by Olsen (1972) in a similar study elsewhere.

Organic carbon contents of the soils: Organic carbon levels of the soil varied significantly $(\mathrm{P}<0.05)$ in the four locations. Yartagimba $(1.64$ $\mathrm{g} / \mathrm{kg}$ ) was highly significantly different from Daiji $(1.38 \mathrm{~g} / \mathrm{kg})$ which was statistically different from Jimajimi $(1.42 \mathrm{~g} / \mathrm{kg})$ and Wassaniya $(1.0 \mathrm{~g} / \mathrm{kg})$ (Table 1). Lower levels of organic carbon were obtained at Wassaniya $(1.0 \mathrm{~g} / \mathrm{kg})$ and Jimajimi $(2.44 \mathrm{~g} / \mathrm{kg})$. This could be attributed to high erosion occasioned by surface run - off.

The levels of organic matter content in the soils were believed to have been influenced by climatic factors such as high temperature and low rainfall as well as uncontrolled bush burning mainly by human influence. The relatively higher organic matter content obtained at Yartagimba and Daiji may be attributed to continuous leaf and grass litter falls within the forest region.

Nitrogen content of the soil $(\mathrm{g} / \mathrm{kg})$ : Analysis of the samples showed that there was no significant difference $(\mathrm{P}>0.05)$ in nitrogen levels of the soil from the four different locations of the study area. The nitrogen contents of the soil were $(0.49 \mathrm{~g} / \mathrm{kg})$, $(0.39 \mathrm{~g} / \mathrm{kg})$ in Wassaniya and Jimajimi, and $(0.28)$ at Yartagimba and Daiji respectively (Table 1). The high nitrogen contents observed may be due to litter fall from the woody species, grasses and shrubs within the forest reserve. The result did not agree with the findings of (Noma, 1998) were soil degradation was prominent.

Available phosphorus: The levels of available phosphorus from the soil analyzed were significantly different $(\mathrm{P}<0.05)$ (Table 1$)$. Daiji $(6.35 \mathrm{mg} / \mathrm{kg})$ was statistically different in phosphorus contents than Jimajimi $(4.10 \mathrm{mg} / \mathrm{kg})$ 
and Yartagimba $(3.77 \mathrm{mg} / \mathrm{kg})$ that were similar. Jimajimi and Yartagimba were also found to be significantly different with Wassaniya (2.41 $\mathrm{mg} / \mathrm{kg}$ ). This was not in agreement with the findings of Noma (1998) at Dabagi with lower records $(0.64 \mathrm{mg} / \mathrm{kg})$.

Exchangeable potassium: Potassium is a vital constituent of all plant and animal tissues. The results indicated that there were no significant differences in potassium concentration from the four locations ( $\mathrm{P}>0.05)$ (Table 1). Yartagimba had the highest value $(0.88 \mathrm{cmol} / \mathrm{kg})$, Wassaniya $(0.72$ $\mathrm{cmol} / \mathrm{kg})$, Daiji $(0.63 \mathrm{cmol} / \mathrm{kg})$ and Jimajimi $(0.62$ $\mathrm{cmol} / \mathrm{kg}$ ). The results showed that potassium levels were generally high which could be attributed to the nature of the parent material in the location. Noma (1998) reported lower concentrations of exchangeable potassium in the soils of Dabagi area.

Exchangeable sodium: Sodium levels were significantly different $(\mathrm{P}<0.05)$ in all the locations
(Table 1). Daiji had the highest concentration $(0.95 \mathrm{cmol} / \mathrm{kg})$, followed by Yartagimba $(0.78$ $\mathrm{cmol} / \mathrm{kg}$ ). The exchangeable sodium in the different locations were statistically different from each other. Jimajimi $(0.52 \mathrm{cmol} / \mathrm{kg})$ while Yartagimba $(0.78 \mathrm{cmol} / \mathrm{kg})$ and Wassaniya $(0.39$ $\mathrm{cmol} / \mathrm{kg}$ ) and Daiji $(0.98 \mathrm{cmol} / \mathrm{kg})$.

Exchangeable calcium: The result indicated that calcium contents were significantly different in the four locations of the study area $(\mathrm{P}<0.05)$ (Table 1). Wassaniya had the highest calcium concentration $(0.95 \mathrm{cmol} / \mathrm{kg})$ followed by Jimajimi $(0.35 \mathrm{cmol} / \mathrm{kg})$. Daiji $(0.20 \mathrm{cmol} / \mathrm{kg})$ was similar to Yartagimba $(0.15 \mathrm{cmol} / \mathrm{kg})$ as there was no any significant difference between them. Higher concentrations of calcium at Wassaniya were mainly due to the parent material which is one of the main charactereristics of Sokoto calcareous soils. Constant leaching may be responsible for lower levels of calcium at Daiji and Yartagimba.

Table 1: Physico-chemical Properties of the Soils of Wassaniya Forest Reserve

\begin{tabular}{|c|c|c|c|c|c|c|}
\hline \multirow[t]{2}{*}{ Parameters } & \multicolumn{3}{|c|}{ Location } & \multirow[b]{2}{*}{ Daiji } & & \\
\hline & Wassaniya & Yartagimba & Timajiri & & & \\
\hline Sand $\mathrm{g} / \mathrm{kg}$ & $347^{\mathrm{b}}$ & $518^{\mathrm{a}}$ & $342^{b}$ & $344^{b}$ & - & - \\
\hline Silt $\mathrm{g} / \mathrm{kg}$ & $269^{b}$ & $171^{\mathrm{c}}$ & $188^{\mathrm{b}}$ & $273^{\mathrm{a}}$ & - & - \\
\hline Clay g/kg & $384^{\mathrm{b}}$ & $311^{\mathrm{c}}$ & $465^{\mathrm{a}}$ & $282^{\mathrm{b}}$ & - & - \\
\hline Textural class & CL & $\mathrm{SL}$ & $\mathrm{C}$ & CL & - & - \\
\hline Soil moisture content (\%) & $8.0^{\mathrm{a}}$ & $8.0^{\mathrm{a}}$ & $9.0^{\mathrm{a}}$ & $7.5 \%{ }^{\mathrm{a}}$ & 4.71 & $*$ \\
\hline Bulk Density $\mathrm{Mg} / \mathrm{m}^{3}$ & $1.29^{\mathrm{a}}$ & $1.32^{\mathrm{a}}$ & $1.20^{\mathrm{a}}$ & $1.27^{\mathrm{a}}$ & 0.98 & $*$ \\
\hline $\mathrm{pH}\left(1: 1 \mathrm{H}_{2} \mathrm{O}\right)$ & $4.33^{\mathrm{b}}$ & $5.47^{\mathrm{bc}}$ & $6.94^{\mathrm{a}}$ & $4.23^{\mathrm{b}}$ & 1.30 & $* *$ \\
\hline $\mathrm{E} \mathrm{C}(\mu \mathrm{s} / \mathrm{m})$ & $185.6^{\mathrm{c}}$ & $134.2^{\mathrm{b}}$ & $125.6^{\mathrm{c}}$ & $186.4^{\mathrm{a}}$ & 5.94 & $* *$ \\
\hline Org C (g/kg) & $1.0^{\mathrm{d}}$ & $1.64^{\mathrm{b}}$ & $1.42^{\mathrm{a}}$ & $1.38^{\mathrm{c}}$ & 0.10 & $* *$ \\
\hline OrgM (g/kg) & $1.72^{\mathrm{d}}$ & $2.82^{\mathrm{a}}$ & $2.44^{\mathrm{b}}$ & $2.37^{\mathrm{c}}$ & 0.03 & $* *$ \\
\hline $\mathrm{N}(\mathrm{g} / \mathrm{kg})$ & $0.49^{\mathrm{a}}$ & $0.28^{\mathrm{a}}$ & $0.39^{\mathrm{a}}$ & $0.28^{\mathrm{a}}$ & 0.26 & $*$ \\
\hline $\mathrm{P}(\mathrm{g} / \mathrm{mg})$ & $2.41^{\mathrm{c}}$ & $3.77^{\mathrm{b}}$ & $4.10^{\mathrm{b}}$ & $6.35^{\mathrm{a}}$ & 0.52 & $* *$ \\
\hline $\mathrm{Ca}(\mathrm{cmol} / \mathrm{kg})$ & $0.95^{\mathrm{a}}$ & $0.15^{\mathrm{c}}$ & $0.35^{\mathrm{b}}$ & $0.20^{c}$ & 0.01 & $* *$ \\
\hline $\mathrm{Mg}(\mathrm{cmol} / \mathrm{kg}$ & $0.20^{\mathrm{c}}$ & $0.20^{\mathrm{c}}$ & $0.45^{\mathrm{b}}$ & $0.72^{\mathrm{a}}$ & 0.12 & $* *$ \\
\hline $\mathrm{K}(\mathrm{cmol} / \mathrm{kg})$ & $0.72^{\mathrm{a}}$ & $0.88^{\mathrm{a}}$ & $0.62^{\mathrm{a}}$ & $0.63^{\mathrm{a}}$ & 0.58 & $*$ \\
\hline $\mathrm{Na}(\mathrm{cmol} / \mathrm{kg})$ & $0.39^{\mathrm{d}}$ & $0.78^{\mathrm{b}}$ & $0.52^{\mathrm{c}}$ & $0.98^{\mathrm{a}}$ & 0.03 & $* *$ \\
\hline $\mathrm{CEC}(\mathrm{cmol} / \mathrm{kg})$ & $2.66^{\mathrm{b}}$ & $2.72^{\mathrm{a}}$ & $2.52^{\mathrm{b}}$ & $2.55^{\mathrm{b}}$ & 0.06 & $* *$ \\
\hline
\end{tabular}

Values with similar superscript on the same colum are not significant (at 0.05 )

$\mathrm{SL}=$ Sandy loam. $\quad \mathrm{CL}=$ Clay loam $\mathrm{C}=$ Clay 
Exchangeable magnesium: The results indicate that there were significant differences in magnesium content of the soils $(\mathrm{P}<0.05)$ (Table 1). Daiji had the highest magnesium content $(0.72 \mathrm{cmol} / \mathrm{kg})$ which was found to be statistically different from Jimajimi $(0.45 \mathrm{cmol} / \mathrm{kg})$. The exchangeable magnessium at Jimajimi location was also statistically different from Wassaniya $(0.20 \mathrm{cmol} / \mathrm{kg})$ and Yartagimba $(0.20 \mathrm{cmol} / \mathrm{kg})$ that had the same concentration $(0.20 \mathrm{cmol} / \mathrm{kg})$. The levels of magnesium obtained in the same soils were adequate and were in conformity with the findings of Noma (1998).

Particle size distribution and moisture content: The soils at the four locations varied in texture from sandy loam (SL) at Yartagimba, clay loam (CL) at Wassaniya and Daiji to clay (C) at Jimajimi. The results indicated that the soils at Jimajimi had the highest moisture contents (9\%) though not statistically significant.

\section{SUMMARY}

The soils at the four locations varied in texture from sandy loam (SL) at Yartagimba, clay loam (CL) at Wassaniya and Daiji to clay (C) at Jimajimi. The results indicated that the soils at Jimajimi had the highest moisture contents (9\%) though not statistically significant. The highest $\mathrm{pH}$ value (6.94) was obtained in the soils of Jimajimi making them slightly alkaline compared with the soils of Yartagimba (5.47) as well as those at Wassaniya and Daiji with $\mathrm{pH}$ values of 4.23 making them acidic in reaction. Yartagimba had the highest Bulk density $\left(1.32 \mathrm{Mg} / \mathrm{m}^{3}\right)$, organic carbon $(1.64 \mathrm{~g} / \mathrm{kg}) \quad$ exchangeable potassium $(0.88 \mathrm{cmol} . / \mathrm{kg})$ as well as highest nitrogen $(0.49 \mathrm{~g} / \mathrm{kg})$ hence the soils are more fertile.

\section{CONCLUSION}

Generally the study revealed that some of the soils are fertile, lightly acidic and sandy loam to clayey in texture. The study also revealed different properties of the soils in the forest reserve as it highlighted in the relationship between the soils and forest trees in the study area. The study therefore recommends that more research should be carried out on the study area so as to clearly link the physico-chemical nature of the soils of the forest reserve and the performance of the trees.

\section{REFERENCES}

Bates, R.C. (1974). Electronic pH Determination, John Wily and sons Inc. New York.

Blakes, G.R. (1965). Particle Density, In: C.A. Black (ed). Methods of Soil Analyses Part 1. American Society of Agronomy Monograph. No.9. Pp 371-373.

Day, P.R. (1956). Report of the Committee on Physical Analyses. 1954-55 Soil Science Soc. Am. Madison, Winscosin.

Evans, L.J., Kay, B.D. and Thomas, R.L. (1987). Soil Science, 1987 ï 2000: A Study Guide and Laboratory Exercise Manual. Department of Land Resource Sciences. University of Guelph, Ontario, Canada.

Illoeje, N.P. (1981). A New Geography for Nigeria. London, Oxford University Press, $200 \mathrm{p}$.

Miller, W.R. and Donahue, L.R. (1965). An Introduction to Soils and Plant Growth $6^{\text {th }}$ Ed., Pretence Hall ltd London. Pp 632.

Noma, S.S. (1998). Rehabilitation of degraded lands, Preliminary studies with Sokoto Soils. An M. Sc. Thesis (Un Published) Submitted to Faculty of Agriculture. University of Ibadan Nigeria

Olaitan, S.O, Lumbin G. and Onazi, O.C. (1988). Introduction to Tropical Soil Science. Macmillan Publishers Ltd. London, Lagos, New York. Pp116

Oslen, S.R. (1972). Micronutrients interactions, pp 243-264 in Micronutrients in Agriculture Mortvedt, J.J. et al. (eds) Soil Science Society of America. Madison, Winscosin.

Walkley, A. and Black, I.A. (1934). An Examination of the Digestrates. Method for Determining Soil Organic Matter and Propose Modification of the Chronic Acid Titration Method. Soil Sci.37: 29-38. 